Research Paper

\title{
Bioprocessing of some agro-industrial residues for endoglucanase production by the new subsp.; Streptomyces albogriseolus subsp. cellulolyticus strain NEAE-J
}

\author{
Noura El-Ahmady El-Naggar ${ }^{1}$, Nayera A.M. Abdelwahed ${ }^{2}$, Wesam I.A. Saber ${ }^{3}$, \\ Asem A. Mohamed ${ }^{2}$ \\ ${ }^{1}$ Department of Bioprocess Development, Genetic Engineering and Biotechnology Research Institute, \\ City of Scientific Research and Technological Applications, Alexandria, Egypt. \\ ${ }^{2}$ Chemistry of Natural and Microbial Products Department, Pharmaceutical Industry Division, \\ National Research Center, Dokki, Cairo, Egypt. \\ ${ }^{3}$ Microbial Activity Unit, Microbiology Department, Soils, Water and Environment Research Institute, \\ Agricultural Research Center, Giza, Egypt.
}

Submitted: January 23, 2013; Approved: September 9, 2013.

\begin{abstract}
The use of low cost agro-industrial residues for the production of industrial enzymes is one of the ways to reduce significantly production costs. Cellulase producing actinomycetes were isolated from soil and decayed agricultural wastes. Among them, a potential culture, strain NEAE-J, was selected and identified on the basis of morphological, cultural, physiological and chemotaxonomic properties, together with $16 \mathrm{~S}$ rDNA sequence. It is proposed that strain NEAE-J should be included in the species Streptomyces albogriseolus as a representative of a novel sub-species, Streptomyces albogriseolus subsp. cellulolyticus strain NEAE-J and sequencing product was deposited in the GenBank database under accession number JN229412. This organism was tested for its ability to produce endoglucanase and release reducing sugars from agro-industrial residues as substrates. Sugarcane bagasse was the most suitable substrate for endoglucanase production. Effects of process variables, namely incubation time, temperature, initial $\mathrm{pH}$ and nitrogen source on production of endoglucanase by submerged fermentation using Streptomyces albogriseolus subsp. cellulolyticus have been studied. Accordingly optimum conditions have been determined. Incubation temperature of $30^{\circ} \mathrm{C}$ after 6 days, $\mathrm{pH}$ of $6.5,1 \%$ sugarcane bagasse as carbon source and peptone as nitrogen source were found to be the optimum for endoglucanase production. Optimization of the process parameters resulted in about 2.6 fold increase in the endoglucanase activity. Therefore, Streptomyces albogriseolus subsp. cellulolyticus coud be potential microorganism for the intended application.
\end{abstract}

Key words: agro-industrial residues, endoglucanase production, Streptomyces albogriseolus, 16S rRNA, scanning electron microscope.

\section{Introduction}

In the recent years, there has been an increasing trend towards more efficient utilization of agro-industrial residues. However, the huge amounts of residual plant biomass considered as waste can potentially be converted into various different value added products including biofuels, chemicals, cheap energy sources for fermentation, improved animal feeds and single cell products (Howard et al., 2003; Ojumu et al., 2003). Agro-industrial wastes have been used as carbon, hydrogen, and oxygen sources to produce ethanol, proteins, and microbial enzymes (Oliveira et al., 2006). One of the largest cellulosic agro-industrial byproducts is sugarcane bagasse. It is a by-product of the sugar industry and is used by the sugar mills as fuel for boilers. There is an increasing trend towards more efficient utilization of agro-

Send correspondence to N. E. El-Naggar. Department of Bioprocess Development, Genetic Engineering and Biotechnology Research Institute, City of Scientific Research and Technological Applications, Bioprocess Department, New Borg El- Arab City, 21934 Alexandria, Egypt. E-mail: nouraelahmady@yahoo.com. 
industrial wastes, including sugarcane bagasse and one of the significant applications is the production of enzymes. Although the economy of such processes is affected by the high cost of product, the utilization of cheaper and indigenous substrates has contributed somewhat to the economical recovery (Pandey et al., 2000).

Endoglucanase (EC 3.2.1.4; endo- $\beta$ - 1, 4 - glucanase) is among the industrially important hydrolytic enzymes, which one of great significance in present day biotechnology. It is found to have potential applications in different industries, like food processing (Galante et al., 1998), animal feed production, pulp and paper industry for various purposes (Ogel et al., 2001), and in detergent and textile industry (Kotchoni et al., 2003) and also for the significant role in bioconversion of agricultural wastes into sugar and bioalcohols. Much research efforts have been focused on lowering the cost of enzymes (El-Naggar et al., 2014). The cost of carbon source plays major role in the economics of endoglucanase production. Hence, an approach to reduce the cost of endoglucanase production is the use of low cost lignocellulosic materials as substrates.

Actinomycetes comprise an extensive and diverse group of Gram-positive, aerobic, largely mycelial bacteria, which play an important ecological role in biodegradation. Many are commercially important, either in useful biological processes such as biodegradation and waste treatment, or in the pro-duction of bioactive compounds such as antibiotics and enzymes (Williams, 1985). Streptomyces species are the most industrially important actinomycetes, due to their capacity to produce numerous secondary metabolites (Berdy, 1995). However, soil isolates Streptomyces lividens (Kluepfel et al., 1986), Streptomyces sp.T3-1(Hsu et al., 2011), S. albaduncus (Harchand and Singh, 1997), S. reticuli (Schrempf and Walter, 1995) and Streptomyces sp. F2621 (Tuncer et al., 2004) have already been reported to produce extracellular endoglucanase significantly in optimized culture media using cellulose powder as carbon source under shaking conditions.

The objectives of the present study were isolation of actinomycete strains, which have cellulolytic activities, selection and identification of a potential strain and also to maximize endoglucanase production by optimizing fermentation conditions using sugarcane bagasse as substrate in order to reduce the cost of production.

\section{Materials and Methods}

\section{Collection of lignocelluloses}

Different agricultural wastes like saw dust, rice husk, rice straw, wheat bran, oatmeal and sugarcane bagasse were collected from local fields of Dakahliyah governorate, Egypt, were oven-dried at $65^{\circ} \mathrm{C}$ for two days to reduce the moisture content and then milled to achieve the size of less than $1 \mathrm{~cm}$.

\section{Microorganisms and cultural conditions}

Streptomyces spp. used in this study were kindly provided by Dr. Noura El-Ahmady El-Naggar (Department of Bioprocess Development, Genetic Engineering and Biotechnology Research Institute, City of Scientific Research and Technologial Applications, Alexandria, Egypt). Streptomyces spp. were isolated from various soil samples collected from different localities of Egypt (32 soil and decayed rice straw samples) and Saudi Arabia (3 soil samples). Actinomycetes from the soil had been isolated using standard dilution plate method procedure on Petri plates containing starch nitrate agar medium (Waksman, 1959) of the following composition $(\mathrm{g} / \mathrm{L})$ : Starch, 20; $\mathrm{KNO}_{3}, 2$; $\mathrm{K}_{2} \mathrm{HPO}_{4}, 1 ; \mathrm{MgSO}_{4} .7 \mathrm{H}_{2} \mathrm{O}, 0.5 ; \mathrm{NaCl}, 0.5 ; \mathrm{CaCO}_{3}, 3$; $\mathrm{FeSO}_{4} .7 \mathrm{H}_{2} \mathrm{O}, 0.01$; agar, 20 and distilled water up to $1 \mathrm{~L}$; then plates were incubated for a period of 7 days at $30^{\circ} \mathrm{C}$. Nystatin $(50 \mu \mathrm{g} / \mathrm{mL})$ was incorporated as an antifungal agent to minimize fungal contamination. Streptomyces isolates were purified and maintained as spore suspensions in $20 \%$ (v/v) glycerol at $-20{ }^{\circ} \mathrm{C}$ (Hopkins et al., 1985) for subsequent investigation.

\section{Plate screening of endoglucanase}

For plate screening, caboxymethylcellulose-agar (CMC-Agar) medium was used. This medium consists of (g/L): CMC, 10.0; $\mathrm{NaNO}_{3}, 1.2 ; \mathrm{KH}_{2} \mathrm{PO}_{4}, 3.0 ; \mathrm{K}_{2} \mathrm{HPO}_{4}, 6.0$; $\mathrm{MgSO}_{4} 7 \mathrm{H}_{2} \mathrm{O}, \quad 0.2 ; \mathrm{CaCl}_{2}, 0.05 ; \mathrm{MnSO}_{4} 7 \mathrm{H}_{2} \mathrm{O}, 0.01$; $\mathrm{ZnSO}_{4} 7 \mathrm{H}_{2} \mathrm{O}, 0.001 ; \mathrm{pH} 7.0$; agar, 20 and distilled water up to $1 \mathrm{~L}$. Agar plates were seeded with spores of actinomycetes and incubated at $30{ }^{\circ} \mathrm{C}$ for 6 days, the cultures were then incubated further at $50{ }^{\circ} \mathrm{C}$ for $18 \mathrm{~h}$ to accelerate the action of extracellular cellulases and thus rapidly develop clearing zone around the cellulase-producing colonies (Montenecourt and Eveleigh, 1977). For cellulolytic activity observations, plates were stained with $0.1 \%(\mathrm{w} / \mathrm{v})$ Congo red dye for 15 min followed by destaining with $1 \mathrm{M}$ $\mathrm{NaCl}$ solution for 15-20 min (Apun et al., 2000), Unstained areas (clear zone of hydrolysis) indicate where the CMC has been broken down to $\beta 1 \rightarrow 4$ glucans that contain seven or fewer glucose residues (Pragya et al., 2012). The diameter of the clear zone can be measured to provide a quantitative comparison of cellulolytic activity. The strain which showed the most promising result was selected for further experiments.

\section{Morphology and cultural characteristics}

The morphology of the spore chain and the spore surface ornamentation of strain NEAE-J were examined on inorganic salt/starch agar (ISP medium 4) after 14 days at $30{ }^{\circ} \mathrm{C}$. The gold-coated dehydrated specimen can be examined at different magnifications with Analytical Scanning Electron Microscope Jeol JSM-6360 LA operating at $20 \mathrm{KV}$ 
at the Central Laboratory, City for Scientific Research and Technological Applications, Alexandria, Egypt. Aerial spore-mass colour, substrate mycelial pigmentation and the production of diffusible pigments were observed on tryptone -yeast extract agar (ISP medium 1), yeast extract-malt extract agar (ISP medium 2), oatmeal agar (ISP medium 3), inorganic salt starch agar (ISP medium 4), glycerol- asparagine agar (ISP medium 5) peptone -yeast extract iron agar (ISP medium 6) and tyrosine agar (ISP medium 7) as described by Shirling and Gottlieb (1966), and on starch-ammonium sulphate agar; all plates were incubated at $30{ }^{\circ} \mathrm{C}$ for 14 days.

\section{Physiological characteristics}

Carbon source utilization was tested on plates of ISP basal medium 9 (Shirling and Gottlieb, 1966) supplemented with a final concentration of $1 \%$ of the tested carbon sources. The plates were incubated at $30{ }^{\circ} \mathrm{C}$ and read after 14 days. Melanoid pigment production was examined on peptone-yeast extract-iron agar (ISP medium 6) and on tyrosine agar (ISP medium 7) (Shirling and Gottlieb, 1966). Growth in the presence of sodium chloride was determined according to Tresner et al. (1968). Degradation of casein was tested following the method of Gordon et al. (1974) and reduction of nitrates to nitrites was examined according to Williams et al. (1983). Liquefaction of gelatin was evaluated by using the method of Waksman (1961). The ability to coagulate or to peptonize milk and hydrogen sulphide production was determined as described by Cowan and Steel (1974). Lecithinase activity was conducted on eggyolk medium according to the method of Nitsch and Kützner (1969) and the capacity to decompose cellulose was tested following the method of Ariffin et al. (2006). The ability of strain to produce $\alpha$-amylase (starch degradation) was determined by streaking onto starch nitrate medium plates containing $2 \%$ soluble starch and incubated at $30{ }^{\circ} \mathrm{C}$ for 7 days. After incubation, the plate is flooded with Gram's iodine solution and zone of clearance was observed (Mishra and Behera, 2008). The ability of the organism to inhibit the growth of four bacterial (Pseudomonas aeruginosa, Staphylococcus aureus, Escherichia coli, or Klebsiella sp.), and five fungal strains (Rhizoctonia solani, Alternaria solani, Bipolaris oryzae, Fusarium oxysporum, Fusarium solani) was determined. Some additional tests can be considered to be useful in completing the description of a strain or species, even if they are not very significant or indicative on their own. The ability of strain NEAE -J to produce uricase (Azab et al., 2005); asparaginase (Gulati et al., 1997) and chitosanase (Choi et al., 2004) were tested.

\section{Chemotaxonomy}

Sugars and diaminopimelic acid isomers were identified by thin-layer chromatography by the method described by Staneck and Roberts (1974).

\section{S rRNA sequencing}

The preparation of genomic DNA of the strain was conducted in accordance with the methods described by Sambrook et al. (1989). The PCR amplification reaction was performed in a total volume of $100 \mu \mathrm{L}$, which contained $1 \mu \mathrm{L}$ DNA, $10 \mu \mathrm{L}$ of $250 \mathrm{mM}$ deoxyribonucleotide 5'-triphosphate (dNTP's); $10 \mu \mathrm{L}$ PCR buffer, 3.5 L $25 \mathrm{mM}$ $\mathrm{MgCl}_{2}$ and $0.5 \mu \mathrm{L}$ Taq polymerase, $4 \mu \mathrm{L}$ of $10 \mathrm{pmol}$ (each) forward $16 \mathrm{~S} \quad$ rRNA primer $27 \mathrm{f}$ (5'-AGAGTTTGATCMTGCCTCAG-3') and reverse 16S rRNA primer 1492r (5'-TACGGYTACCTTGTTACGACTT-3') and water was added up to $100 \mu \mathrm{L}$. The PCR-Apparatus was programmed as follows: 5 min denaturation at $94^{\circ} \mathrm{C}$, followed by 35 amplification cycles of $1 \mathrm{~min}$ at $94{ }^{\circ} \mathrm{C}, 1 \mathrm{~min}$ of annealing at $55^{\circ} \mathrm{C}$, and $2 \mathrm{~min}$ of extension at $72{ }^{\circ} \mathrm{C}$, followed by a $10 \mathrm{~min}$ final extension at $72^{\circ} \mathrm{C}$. The PCR reaction mixture was then analyzed via agarose gel electrophoresis, and the remaining mixture was purified using QIA quick PCR purification reagents (Qiagen, USA). The purified PCR product of approximately $1400 \mathrm{bp}$ was sequenced by using two primers, 518F; 5'-CCA GCA GCC GCG GTA ATA CG-3' and 800R; 5'-TAC CAG GGT ATC TAA TCC-3'. Sequencing was performed by using Big Dye terminator cycle sequencing kit (Applied BioSystems, USA). Sequencing product was resolved on an Applied Biosystems model 3730XL automated DNA sequencing system (Applied BioSystems, USA) and deposited in the GenBank database under accession number JN229412.

\section{Sequence alignment and phylogenetic analysis}

The nearly complete resultant $16 \mathrm{~S}$ rRNA gene sequence (1006 nucleotides) of strain NEAE-J was aligned with the corresponding $16 \mathrm{~S}$ rRNA sequences of the type strains of representative members of the genus Streptomyces retrieved from the GenBank, EMBL, DDBJ and PDB databases by using BLAST program (www.ncbi.nlm.nih. gov/blst) (Altschul et al., 1997). The software package MEGA4 version 2.1 (Tamura et al., 2007) was used for multiple alignment and phylogenetic analysis. The phylogenetic tree was constructed via the neighbor-joining algorithm (Saitou and Nei, 1987) based on the 16S rRNA gene sequences of strain NEAE-J and related organisms.

\section{Fermentation conditions for endoglucanase production and saccharification}

Submerged fermentation for enzyme production was carried out in Erlenmeyer flasks $(250 \mathrm{~mL})$ containing $50 \mathrm{~mL}$ of the production medium containing $(\mathrm{g} / \mathrm{L})$ : sugarcane bagasse, 10.0; $\mathrm{NaNO}_{3}, 1.2 ; \mathrm{KH}_{2} \mathrm{PO}_{4}, 3.0 ; \mathrm{K}_{2} \mathrm{HPO}$, 6.0; $\mathrm{MgSO} 47 \mathrm{H}_{2} \mathrm{O}, 0.2 ; \mathrm{CaCl}_{2}, 0.05 ; \mathrm{MnSO}_{4} 7 \mathrm{H}_{2} \mathrm{O}, 0.01$; $\mathrm{ZnSO}_{4} 7 \mathrm{H}_{2} \mathrm{O}, 0.001$; yeast extract, 0.5 and distilled water up to $1 \mathrm{~L}$. The $\mathrm{pH}$ was adjusted to 7.0. The flasks were auto- 
claved at $121{ }^{\circ} \mathrm{C}$ for $20 \mathrm{~min}$, inoculated with three agar disks of $9 \mathrm{~mm}$ diameter taken from 7 days old stock culture (According to the method of Gill et al. (2003) and incubated at $30^{\circ} \mathrm{C}$ for 6 days on a rotary shaker at $200 \mathrm{rpm}$. After incubation period, the cells were removed by centrifugation at $5000 \mathrm{rpm}$; the mycelium free supernatant was used as a crude enzyme for estimation of endoglucanase activity, the total protein and saccharification percentage.

For optimizing the fermentation conditions for both endoglucanase production and saccharification percentage, various parameters were studied for maximal enzyme production as follows: Different types of carbon sources for the induction of endoglucanase i.e., cellobiose, cellulose powder, carboxymethyl cellulose, rice straw, wheat bran, sugarcane bagasse, saw dust, rice husk, oatmeal, xylan, sucrose and starch, which were separately added as a sole carbon source to the culture media at concentration of $1 \%$ $(w / v)$. Sugarcane bagasse was then added to the basal salt media at several concentrations $(0.5$ to $2 \%$; w/v). Media were inoculated and incubated at $30^{\circ} \mathrm{C}$ for 6 days with shaking at $200 \mathrm{rpm}$. The effect of incubation period was evaluated at $24 \mathrm{~h}$ interval. The effect of temperature on the production of endoglucanase was determined at various temperatures ranging from 20 to $50^{\circ} \mathrm{C}$ at $\mathrm{pH}$ 6.5. The effect of $\mathrm{pH}$-value on the production of endoglucanase was studied at various $\mathrm{pH}$ values ranging from 4.0 to 9.0. The effect of supplementation of nitrogen sources was examined using nitrogen sources like were ammonium chloride, ammonium phosphate, potassium nitrate, sodium nitrate, urea, yeast extract, peptone. Different nitrogen sources prepared at equivalent nitrogen bases were used separately as nitrogen source in production medium. Whereas, a control represented by production medium without additional nitrogen source was performed at the same time.

\section{Endoglucanase assay}

Endoglucanase activity in culture supernatant was determined according to Miller (1959). A reaction mixture of $0.25 \mathrm{~mL}$ of $1 \%(\mathrm{w} / \mathrm{v})$ carboxymethyl cellulose (CMC, sodium salt, low viscosity, Sigma Chemical Co., St. Louis, MO, USA) solution in MCIlvaine buffer ( $\mathrm{pH}$ 6), and $0.25 \mathrm{~mL}$ of culture supernatant was incubated at $45^{\circ} \mathrm{C}$ for 40 min (Blanks were prepared in the same way and boiled for $5 \mathrm{~min}$ ). After incubation, the enzyme activity was stopped by adding $1.5 \mathrm{~mL}$ DNS-reagent; tubes were placed in a boiling water bath for $15 \mathrm{~min}$, cooled down to room temperature. The O.D. of the samples was immediately measured at $540 \mathrm{~nm}$. The determination was carried out in duplicate. Endoglucanase is expressed in terms of units. One unit of endoglucanase activity was defined as the amount of enzyme required to release $1 \mu$ mole reducing sugars per minute per $\mathrm{mL}$ under the assay conditions by using glucose as a standard.

\section{Estimation of total proteins}

Total protein in culture filtrate was determined by the method of Lowry et al. (1951), using bovine serum albumin as standard.

\section{Saccharification}

The percentage of saccharification was calculated by applying the equation of Alam et al. (2004):

Saccharification $(\%)=\frac{\mathrm{mg} \text { of reducing sugar } / \mathrm{mL}}{\mathrm{mg} \text { of substrate } / \mathrm{mL}} \times 100$

\section{Results and Discussion}

A total of one hundred forty one morphologically different actinomycete strains were recovered from 35 samples, which were collected from different localities in Egypt and Saudi Arabia. Actinomycetes strains were examined for cellulolytic activities on CMC- containing agar plates. Upon initial screening, it appeared that most of the isolates (77.3\%) were able to develop clear surrounding zone indicating cellulolytic activities and cellulase production while only $22.7 \%$ of the isolates were unable to produce this enzyme. Cellulase producing isolates were categorized into 4 groups according to the width of inhibition zones; very strong (>30 mm), strong (21-30 mm), moderate (11-20 mm), weak $(1-10 \mathrm{~mm})$, the four groups were represented by $1.42,44.68$, 29.79 and $1.42 \%$ activity, respectively (Figure 1a). Strain NEAE-J showed large clear zone diameter around its colonies (Figure 1b). The cellulolytic activity of the selected strain was confirmed under submerged fermentation indicating the highest cellulose degradation.

\section{Cultural and morphological characteristics of the isolate NEAE-J}

The colonial morphology of strain NEAE-J was consistent with its assignment to the genus Streptomyces (Williams et al., 1989). It formed an extensively branched substrate mycelium and aerial hyphae. The aerial spore mass was grey colored on several standard media (Figure 2). The reverse sides of colonies are faint-brown on most agar media (Table 1). The color of the substrate mycelium is not $\mathrm{pH}$ sensitive and faint brown diffusible pigments were produced on inorganic salt-starch agar medium (ISP medium 4).

The organism formed a highly branched substrate mycelium and aerial hyphae which differentiated into long rectiflexibiles spore chains carrying more than 50, smooth-surfaced spores $(0.62 \times 0.881 \mu \mathrm{m}$ in diameter $)$ as shown by the scanning electron micrograph (Figure 3 ).

Strain NEAE -J can be differentiated from $S$. albogriseolus and other closest phylogenetic neighbours by many features (Table 2) in that it produced a gray aerial mycelium, brown substrate mycelial pigment and produce faint brown diffusible pigment on ISP2 medium while $S$. 

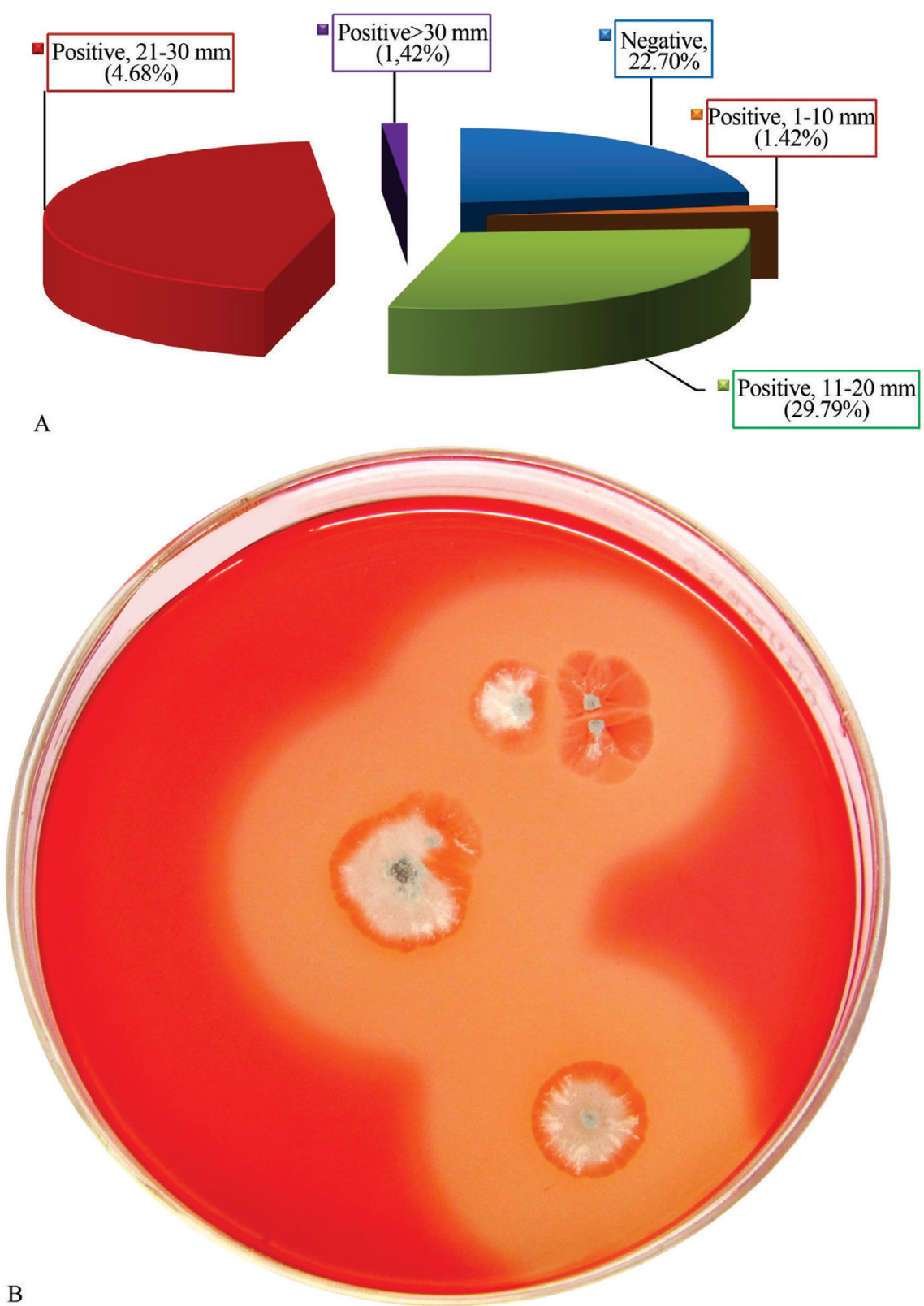

Figure 1 - A- Screening of actinomycetes isolates for the degradation of caboxymethylcellulose on CMC-agar (percentage inside the parenthesis indicates the frequency of actinomycetes isolates within specific category in relation to the total isolates). B- Cellulolytic activity of Streptomyces sp. NEAE $-\mathrm{J}$ on cellulose agar indicated by clearing zone surrounding the colony.

albogriseolus produced gray aerial mycelium, yellow/ brown substrate mycelium pigment and did not produce a diffusible pigment on ISP2 medium (Benedict et al., 1954); $S$. carnosus produced a grey aerial mycelium, grayish yellow to orange yellow or brown substrate mycelial and pale pink or yellow diffusible pigment in oatmeal agar and glycerol-asparagine agar (Waksman and Lechevalier, 1953); $S$. litmocidini produced a grey aerial mycelium, colorless or grayed yellow substrate mycelial and violet, blue or red diffusible pigment (Pridham et al., 1958)and S. pactum produced a beige aerial mycelium, grey substrate mycelial and beige diffusible pigment (Bhuyan et al., 1962).

\section{Physiological characteristics of the isolate NEAE-J}

The physiological and biochemical reactions of strain NEAE-J are shown in Table 2. Melanoid pigments not formed neither in peptone-yeast extract iron agar (ISP medium 6) or tyrosine agar (ISP medium 7). As the sole carbon source, Streptomyces NEAE-J utilizes D-glucose, D-xylose, D-fructose, D-maltose, D-mannose, rhamnose, raffinose, L-arabinose and cellulose for growth. Ribose and gluconic acid are not utilized. Some growth occurs with galactose and sucrose as the carbon source. The strain degrades casein, gelatin, cellulose and starch. Lecithinase ac- 


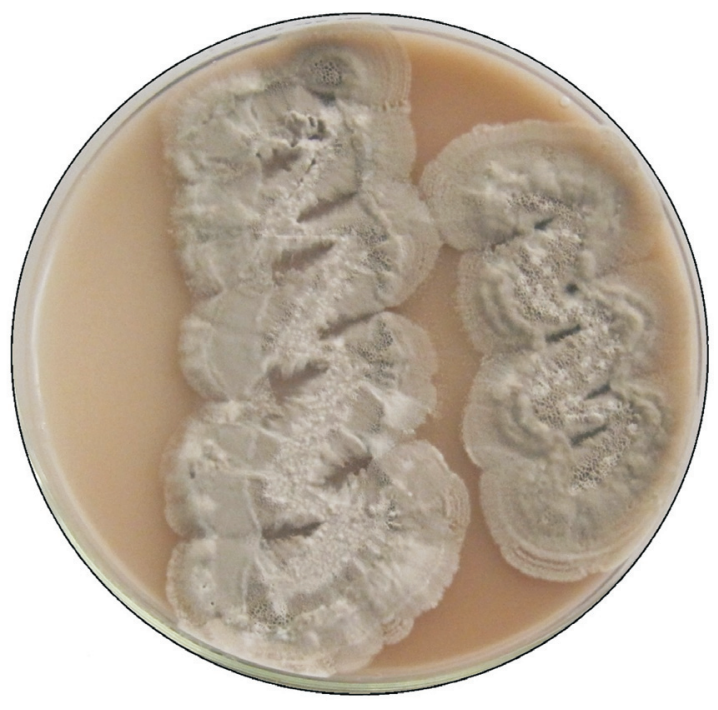

Figure 2 - Color of the aerial mycelium of Streptomyces strain grown on starch -nitrate agar medium for 14 days of incubation at $30^{\circ} \mathrm{C}$.

tivity, nitrate reduction and hydrogen sulphide production were negative. Coaggulation of milk was doubtful. Protease, cellulase, amylase, uricase and chitosanase were produced L-asparaginase. The optimal growth temperature of strain NEAE-J was $30{ }^{\circ} \mathrm{C}$ and optimal $\mathrm{pH}$ was 7.0.

Compared with $S$. albogriseolus (Benedict et al., 1954), strain NEAE -J differed in a number of characteristics, including antimicrobial activities and sucrose utilization. Compared with S. carnosus (Waksman and Lechevalier, 1953), differences were observed in reduction of nitrates to nitrite, utilization of $\mathrm{D}(+)$ xylose, sucrose and L-arabinose, coaggulation and peptonization of milk. Strain NEAE -J differed from $S$. litmocidini in some characteristics, including sensitivity of diffusible pigment to $\mathrm{pH}$, melanin production and utilization of $\mathrm{D}(-)$ fructose, $\mathrm{D}(+)$ xylose sucrose and raffinose (Pridham et al., 1958). S. pactum also showed some differences in relation to strain NEAE -J, including the antimicrobial activities and utilization of $\mathrm{D}(-)$ fructose, $\mathrm{D}(+)$ xylose, $\mathrm{D}(+)$ mannose, sucrose, cellulose, rhamnose, raffinose and L-arabinose (Bhuyan et al., 1962).

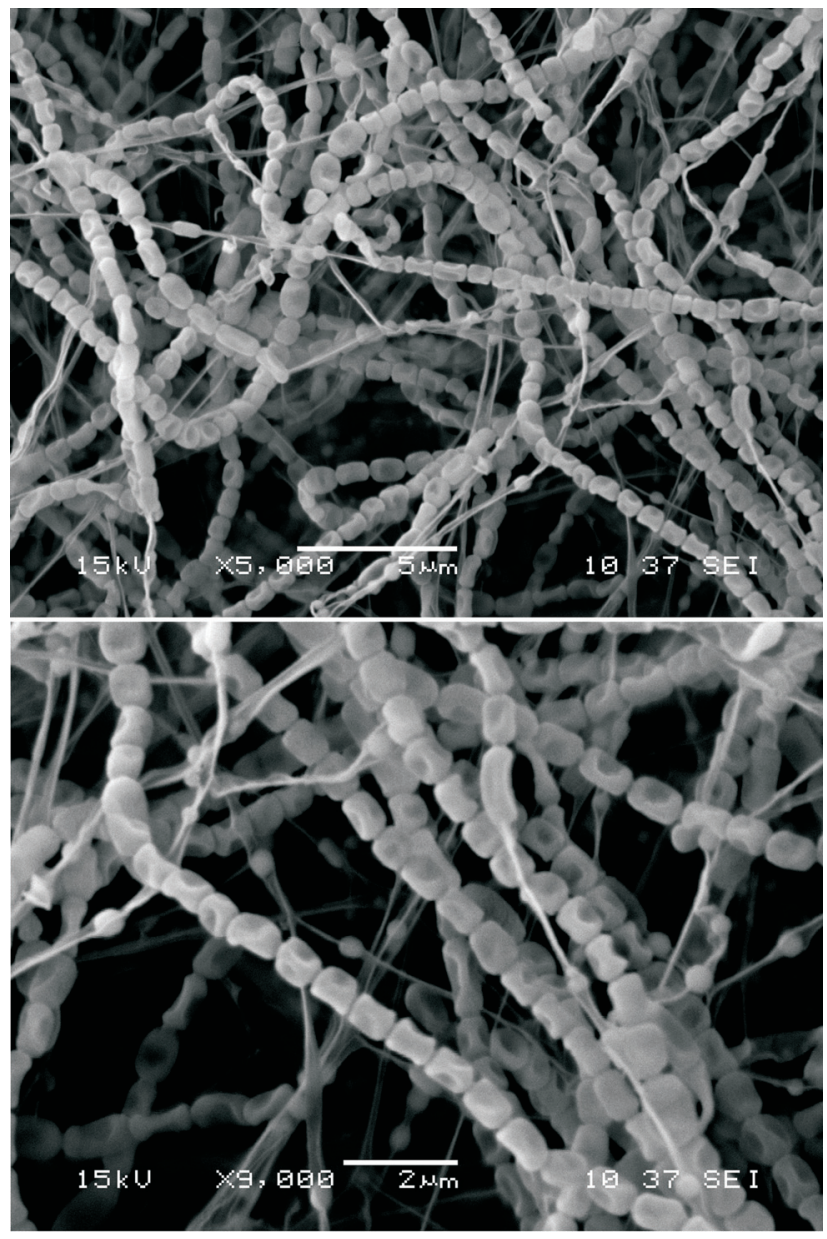

Figure 3 - Scanning electron micrograph showing the spore-chain morphology and spore-surface ornamentation of strain NEAE-J grown on starch nitrate agar medium for 14 days at $30^{\circ} \mathrm{C}$ at magnification of $5000 \mathrm{X}$ and $9000 \mathrm{X}$

\section{Chemotaxonomy of the isolate NEAE-J}

Chemotaxonomic tests showed that the cell wall contained LL-diaminopimelic acid in whole-organism hydrolysates, indicating that it was of cell-wall type I (Lechevalier and Lechevalier, 1970) but no characteristic sugars were found in the strain.

Table 1 - Culture properties of the Streptomyces isolate NEAE-J.

\begin{tabular}{|c|c|c|c|c|}
\hline Medium & Aerial mycelium & Substrate mycelium & $\begin{array}{c}\text { Diffusible } \\
\text { pigment }\end{array}$ & Growth \\
\hline ISP 2 medium (Yeast extract -malt extract agar) & Gray & Faint brown & Non-pigmented & Excellent \\
\hline ISP 3 medium (Oatmeal agar) & Whitish gray & Faint brown & Non-pigmented & Excellent \\
\hline ISP 4 medium (Inorganic salt-starch agar) & Gray & Faint brown & Faint brown & Excellent \\
\hline ISP 5 medium (Glycerol asparagines agar) & Faint growth with white margins & Faint yellow (Not distinctive) & Non-pigmented & Weak \\
\hline ISP 6 medium (Peptone-yeast extract iron agar) & No-sporulation & No-sporulation & Non-pigmented & Weak \\
\hline ISP 7 medium (Tyrosine agar) & Faint gray & Brown & Non-pigmented & Excellent \\
\hline Starch ammonium sulphate & Gray & Faint yellow (Not distinctive) & Non-pigmented & Excellent \\
\hline
\end{tabular}


Table 2 - Phenotypic properties that separate strain Streptomyces NEAE-J from related Streptomyces species. S. albogriseolus (Benedict et al., 1954), S. carnosus (Waksman and Lechevalier, 1953), S. litmocidini (Pridham et al., 1958). S. pactum (Bhuyan et al., 1962).

\begin{tabular}{|c|c|c|c|c|c|}
\hline Characteristic & $\begin{array}{l}\text { Streptomyces } \\
\text { NEAE-J }^{1}\end{array}$ & S. albogriseolus & S. carnosus & S. litmocidini & S. pactum \\
\hline Aerial mycelium on ISP medium 2 & Gray & Gray & Gray & Gray & Beige \\
\hline Substrate mycelium on ISP medium 2 & brown & yellow/ brown & $\begin{array}{l}\text { Grayish yellow to orange yellow } \\
\text { or brown }\end{array}$ & $\begin{array}{l}\text { Colorless or } \\
\text { grayed yellow }\end{array}$ & grey \\
\hline Production of diffusible pigment & Faint brown & - & $\begin{array}{l}\text { Pale pink or yellow in oatmeal } \\
\text { agar and glycerol-asparagine agar }\end{array}$ & $\begin{array}{l}\text { Violet, blue or } \\
\text { red }\end{array}$ & beige \\
\hline Spore chain morphology & $\mathrm{RF}$ & $\mathrm{RF}$ & RA or Spirales & $\mathrm{RF}$ or RA & RA \\
\hline Number of spores /chain & & & $10-50$ & $10-50$ & \\
\hline Spore surface & Smooth & Smooth & Smooth & Smooth & Smooth \\
\hline Spore shape & Elongated & & Cylindrical & Cylindrical & \\
\hline Sensitivity of diffusible pigment to $\mathrm{pH}$ & - & & - & $+^{2}$ & \\
\hline $\begin{array}{l}\text { Melanin production on tyrosine agar } \\
\text { (ISP medium 7) }\end{array}$ & - & & - & - & - \\
\hline $\begin{array}{l}\text { Melanin production on peptone-yeast } \\
\text { extract iron agar (ISP medium 6) }\end{array}$ & - & & - & + & - \\
\hline \multicolumn{6}{|l|}{ Degradation of } \\
\hline Casein & + & & & & \\
\hline Gelatin & + & + & liquefaction rapid & & \\
\hline Starch & + & & & & \\
\hline $\mathrm{Max} \mathrm{NaCl}$ tolerance $(+, \mathrm{w} / \mathrm{v})$ & $5 \%$ & $5 \%$ & & & \\
\hline \multicolumn{6}{|l|}{ Growth on sole carbon source $(1+, w / v)$} \\
\hline D(-) Fructose & + & + & & \pm & - \\
\hline $\mathrm{D}(+)$ Xylose & + & + & \pm & \pm & - \\
\hline $\mathrm{D}(+)$ Glucose & + & + & + & + & + \\
\hline $\mathrm{D}(+)$ Mannose & + & + & & & - \\
\hline Sucrose & \pm & + & \pm & \pm & - \\
\hline $\mathrm{D}(+)$ Galactose & \pm & & & & \\
\hline Cellulose & + & + & & & - \\
\hline Rhamnose & + & + & + & & - \\
\hline Raffinose & + & + & & \pm & - \\
\hline L-arabinose & + & + & \pm & + & - \\
\hline Ribose & - & & & & \\
\hline Gluconic acid & - & & & & \\
\hline Reduction of nitrates to nitrite & - & & + & & \\
\hline Lecithinase activity & - & & & & \\
\hline $\mathrm{H}_{2} \mathrm{~S}$ production & - & - & & & - \\
\hline Coaggulation of milk & \pm & & + & & \\
\hline Peptonization of milk & \pm & & + & & \\
\hline Antimicrobial activities & - & $+^{3}$ & & & $+^{4}$ \\
\hline
\end{tabular}

${ }^{1}$ Protease, cellulase, amylase, L-asparaginase, uricase and chitosanase of Streptomyces NEAE-J were produced. The optimal growth temperature was 30 ${ }^{\circ} \mathrm{C}$ and optimal $\mathrm{pH}$ was 7.0 .

${ }^{2}$ Reverse color is changed from violet to blue by addition of $0.05 \mathrm{~N} \mathrm{NaOH}$ and from violet to red with $0.05 \mathrm{~N} \mathrm{HC1}$.

${ }^{3}$ Produce Amphomycin and Cephamycin antibiotics that active against gram positive bacteria. Produce Vineomacin that has antibacterial and antitumor activities.

${ }^{4}$ Produce Pactamycin, antitumor antibiotic and others.

Abbreviations: RF, Rectiflexibiles; RA, Retinaculiaperti; S, Spirales; +, Positive; -, Negative; \pm , Doubtful; Blank cells, no data available. 


\section{Molecular phylogeny of the isolate NEAE-J}

The nearly complete 16S rRNA gene sequence (1006 nucleotides) for the strain NEAE-J was aligned with other 16S rRNA sequences of representative Streptomyces species retrieved from the GenBank, EMBL and DDBJ databases by using BLAST searches (Altschul et al., 1997). The phylogenetic tree (Figure 4) based on the 16S rRNA gene sequences of strain NEAE-J and the most closely related type strains of the genus Streptomyces was constructed according to the neighbour-joining method of Saitou and Nei (1987) with MEGA4 (Tamura et al., 2007). The phylogenetic analysis indicated that strain NEAE-J formed a distinct branch with two other Streptomyces species, Streptomyces pactum strain 173848 (GenBank/ EMBL/DDBJ accession no. EU593609.1) $(99.0 \%$ sequence similarity) and Streptomyces albogriseolus strain HBUM174069 (GenBank/EMBL/DDBJ accession no. FJ486338.1) ( $99.0 \%$ sequence similarity). The comparative study between strain NEAE-J and its closest phylogenetic neighbours, however, revealed significant differences from those Streptomyces species as summarized in Table 2.

From the taxonomic features, the cellulolytic strain NEAE-J matches with Streptomyces albogriseolus in most morphological, physiological and biochemical characters and differed in some characteristics, including antimicrobial activities, production of diffusible pigment and utilization of sucrose. Therefore, it is proposed that strain NEAE-J should be included in the genus Streptomyces albogriseolus as a representative of a novel sub-species, Streptomyces albogriseolus subsp. cellulolyticus stain NEAE-J.

\section{Description of Streptomyces albogriseolus subsp. cellulolyticus. nov.}

Streptomyces albogriseolus subsp. cellulolyticus (cellulolyticus pertaining to cel.lu.lo.1y'ti.cus. M. L. n. cellulosum, cellulose; Gr. adj. lyticus, dissolving; M. L. adj. cellulolyticus, decomposing cellulose).
Aerobic, Gram-positive mesophilic actinomycete which forms an extensively branched substrate mycelium and aerial hyphae that differentiate into long rectiflexibiles spore chains with more than 50 smooth-surfaced spores per chain. Some unicellular spherical bodies are produced separately in some mycelial filament. It developed grey coloured aerial mycelium and faint brown substrate mycelium on yeast extract -malt extract agar. The colour of the substrate mycelium was not sensitive to changes in $\mathrm{pH}$. Verticils are not present. The mycelium does not fragment. A diffusible faint brown pigment is produced in inorganic salt-starch agar. Melanin pigments are not produced on peptone/yeast extract/ iron or tyrosine agar. Additional cultural characteristics on various agar media are given in Table 1 . Growth occurs between 20 and $40^{\circ} \mathrm{C}$ and between $\mathrm{pH} 4.0$ and 10.0. The optimal growth temperature was $30^{\circ} \mathrm{C}$ and optimal $\mathrm{pH}$ was 7.0. The cell wall peptidoglycan contains LL-diaminopimelic acid (chemotype I cell wall). Strain NEAE-J grew well on yeast extract - malt extract agar (ISP medium 2), oatmeal agar (ISP medium 3), inorganic salt-starch agar (ISP medium 4), tyrosine agar (ISP medium 7) and starchammonium sulphate agar medium. It exhibited weak growth on glycerol-asparagine agar (ISP medium 5) and peptoneyeast extract iron agar (ISP medium 6). Gelatin liquifications, growth on cellulose and starch hydrolysis (Figure 5) were positive. Lecithinase activity, nitrate reduction, melanin production, and hydrogen sulphide production were negative. Coaggulation of milk was doubtful. Protease, cellulase, amylase, uricase and chitosanase are produced L-asparaginase.

D-glucose, D-xylose, D-fructose, D-maltose, D-mannose, rhamnose, raffinose, L-arabinose and cellulose were utilized but not ribose and gluconic acid. Galactose and sucrose were doubtful. It did not exhibit any antimicrobial activity against Pseudomonas aeruginosa, Staphylococcus aureus, Escherichia coli, Klebsiella sp., Rhizoctonia solani, Alternaria solani, Bipolaris oryzae, Fusarium oxysporum or Fusarium solani.

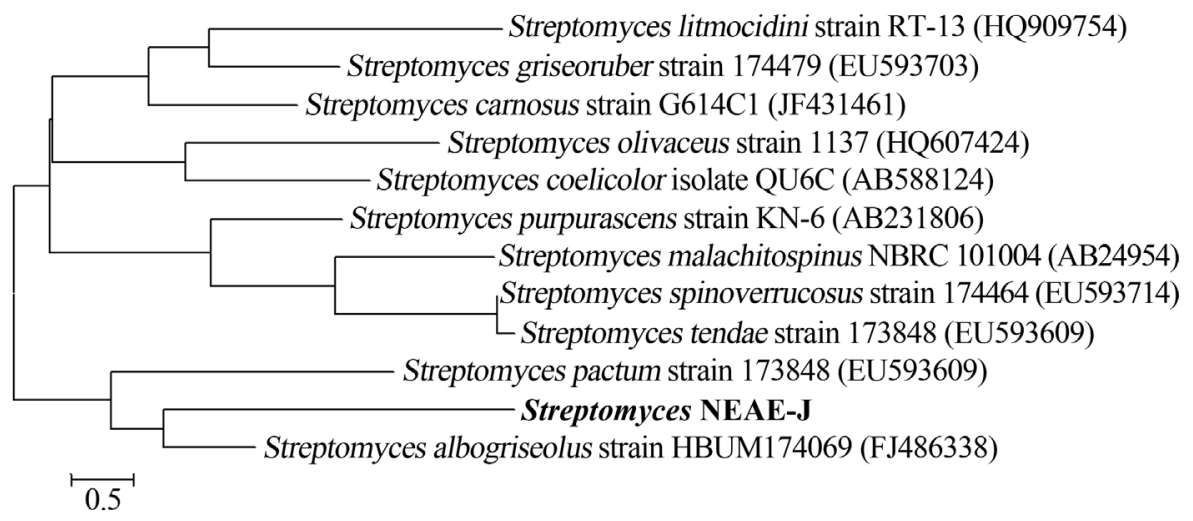

Figure 4 - Neighbour-joining phylogenetic tree based on 16S rRNA gene sequences, showing the relationships between strain NEAE-J and related species of the genus Streptomyces. GenBank sequence accession numbers are indicated in parentheses after the strain names. 




Figure 5 - Plate assay showing zone of hydrolysis of starch by strain NEAE 102. All the starch in the medium around the microbe has been hydrolyzed by extracellular amylases.

\section{Endoglucanase production by $S$. albogriseolus subsp. cellulolyticus using different agro-industrial residues as carbon source}

A comparative study was conducted to determine the suitability of common agro-industrial residues as well as some others carbon sources for endoglucanase production by Streptomyces albogriseolus subsp. cellulolyticus with that of control in which carboxymethyl cellulose is amended instead of agriculture by-products (Table 3a). Obtained data clearly show that endoglucanase was produced on the different sources used, but some of these sources reduced the enzyme biosynthesis, while other induced it greatly. Among these, xylan, sucrose, starch, inulin, oat- meal and cellobiose had no significant stimulating effect on endoglucanase production by the tested strain while sugarcane bagasse, cellulose powder, rice straw, saw dust, wheat bran and rice husk significantly enhanced endoglucanase production as compared to that on pure CMC. This means that, this enzyme is constitutive in their nature and induced with its substrates. However, the maximum endoglucanase yield was achieved by sugarcane bagasse $(41.54 \mathrm{U} / \mathrm{mL})$ while the minimum production was recorded in presence of sucrose as carbon source $(14.07 \mathrm{U} / \mathrm{mL})$. Chellapandi and Himamhy (2008) showed that starch and maltose repressed endoglucanase production by Streptomyces sp. BRC1 and $\mathrm{BRC} 2$ respectively while glucose and cellobiose showed as good inducers to form endoglucanase by these isolates. El-Naggar et al. (2011) applied actinobacteria on rice straw composting and found their efficiency in rice straw decomposition. Production of this enzyme by a strain of Streptomyces sp. HM29 occurred with higher yields when the strain was grown on bagasse in comparison to rice straw, rye straw or corncobs (Modi et al., 1994).

There were evidences for the efficiency of the biodegradation of the different carbon sources by the isolated strain. The evidences are the estimated amounts of reducing sugars and the saccharification, occurred on the different substrates, which reached, to the maximum in the case of sugarcane bagasses. The positive significant correlation coefficient between enzyme production and saccharification $(r=0.999$ at $p \leq 0.01)$ confirmed the strong action of the endoglucanase. The specific activity of endoglucanase varied on different substrate, this may be back to the different growth patterns of Streptomyces strain as a response to various nature of the different carbon sources, CMC showed the highest value $(26.51 \mathrm{U} / \mathrm{mg}$ protein) in this respect. The specific activity of endoglucanase, resulted from $S$. albogriseolus subsp. cellulolyticus grown on different carbon sources did not show specific trend. This may be back

Table 3a - Endoglucanase production and biodegradation of different carbon sources by S. albogriseolus subsp. cellulolyticus.

\begin{tabular}{|c|c|c|c|c|}
\hline Carbon Source & $\begin{array}{l}\text { Endoglucanase activity } \\
(\mathrm{U} / \mathrm{mL})\end{array}$ & $\begin{array}{l}\text { Specific activity } \\
\text { (U/mg protein) }\end{array}$ & $\begin{array}{l}\text { Reducing sugars } \\
(\mathrm{mg} / \mathrm{mL})\end{array}$ & $\begin{array}{c}\text { Saccharification } \\
(\%)\end{array}$ \\
\hline CMC (control) & 30.09 & 26.51 & 1.083 & 10.83 \\
\hline Cellulose & 34.27 & 19.73 & 1.233 & 12.33 \\
\hline Cellobiose & 18.45 & 10.72 & 0.664 & 6.64 \\
\hline Rice husk & 30.59 & 14.77 & 1.101 & 11.01 \\
\hline Rice straw & 33.25 & 20.52 & 1.196 & 11.96 \\
\hline Saw dust & 32.67 & 13.25 & 1.176 & 11.76 \\
\hline Sugarcane bagasse & 41.54 & 17.23 & 1.495 & 14.95 \\
\hline Wheat bran & 31.86 & 18.29 & 1.146 & 11.46 \\
\hline Oatmeal & 28.13 & 15.93 & 1.012 & 10.12 \\
\hline Sucrose & 14.07 & 3.08 & 0.506 & 5.06 \\
\hline Starch & 19.41 & 13.84 & 0.698 & 6.98 \\
\hline Xylan & 24.28 & 16.76 & 0.874 & 8.74 \\
\hline
\end{tabular}


to the different composition of carbon source which led to various growth natures of $S$. albogriseolus subsp. cellulolyticus, resulting different types of protein in the growth media. Therefore, no much dependency could be relying on such parameter. Accordingly, different concentrations of sugarcane bagasse $(0.5,1.0,1.5$ and $2 \%$; w/v) were added to the cultivation medium. The maximum endoglucanase yield was obtained at $1.0 \%$ of sugarcane bagasse (Table $3 \mathrm{~b}$ ). The results of sugarcane bagasse follow the nature curve in which the peak of saccharification and enzyme production was at $1 \%$ with positive correlation $(\mathrm{r}=0.999$ at $\mathrm{p} \leq 0.01)$, confirming the data of Table $3 \mathrm{a}$.

The carbon source has been estimated as a major cost factor in enzyme production. Industrial application of endoglucanase, however, would only be feasible if the carbon sources were available in large quantities at competitive price. A reduction in the production cost can be achieved by the usage of inexpensive crude raw materials of agricultural origin, which are cheap, easily available, often abundant, alternative, for large-scale fermentation.

\section{Effect of incubation period on endoglucanase production}

It is observed from the results in the Figure 6 that the endoglucanase production gradually raised and reached its maximum activities $(57.69 \mathrm{U} / \mathrm{mL})$ after 6 days incubation, then gradually decreased. Additionally, all the tested parameters (specific activity, reducing sugars and saccharification) follow the same trend. This decline after the maximum peak of enzyme secretion could be attributed to catabolic repression by glucose, since the maximum amount of glucose was accumulated at the $6^{\text {th }}$ day. Cellulase production is growth related, so, depletion of carbon and nitrogen sources causes starvation and hence the microorganism may not grow as reported by Dosoretz et al. (1990). The depression in cellulase activity may also be due to cumulative effect of cellobiose, a dimer of glucose which is known to inhibit endogluconase activity (Ojumu et al., 2003).

\section{Effect of temperature on endoglucanase production}

As shown in Figure 7, the enzyme showed a good production between 25 to $40^{\circ} \mathrm{C}$ with maximum endoglucanase production $(67.61 \mathrm{U} / \mathrm{mL})$, reducing sugars $(2.43 \mathrm{mg} / \mathrm{mL})$ and saccharification $(24.33 \mathrm{mg} / \mathrm{mL})$ at $30^{\circ} \mathrm{C}$. Out this temperature, the enzyme production gradually reduced and the decrease is probably due to enzyme denaturation and conformation change, as enzymes are proteins. Our results are in accordance with two previous reports on endoglucanase by Streptomyces sp. F2621 (Tuncer et al., 2004) and $S$. albogriseous (Van Zyl, 1985) which exhibited maximum endoglucanase activity at $26-30{ }^{\circ} \mathrm{C}$. On the other hand, the results reported by El-Naggar and Abdelwahed (2012)

Table 3b - Effect of different sugarcane bagasse concentration on endoglucanase production, reducing sugars level and saccharification by $S$. albogriseolus subsp. cellulolyticus.

\begin{tabular}{lcccc}
\hline $\begin{array}{l}\text { Carbon source concentration } \\
(\%)\end{array}$ & $\begin{array}{c}\text { Endoglucanase activity } \\
(\mathrm{U} / \mathrm{mL})\end{array}$ & $\begin{array}{c}\text { Specific activity } \\
(\mathrm{U} / \mathrm{mg} \text { protein })\end{array}$ & $\begin{array}{c}\text { Reducing sugars } \\
(\mathrm{mg} / \mathrm{mL})\end{array}$ & $\begin{array}{c}\text { Saccharification } \\
(\%)\end{array}$ \\
\hline 0.5 & 30.86 & 16.05 & 1.11 & 11.10 \\
1 & 43.50 & 19.70 & 1.57 & 15.65 \\
1.5 & 41.45 & 18.31 & 1.49 & 14.92 \\
2 & 34.30 & 13.09 & 1.23 & 12.34 \\
\hline
\end{tabular}

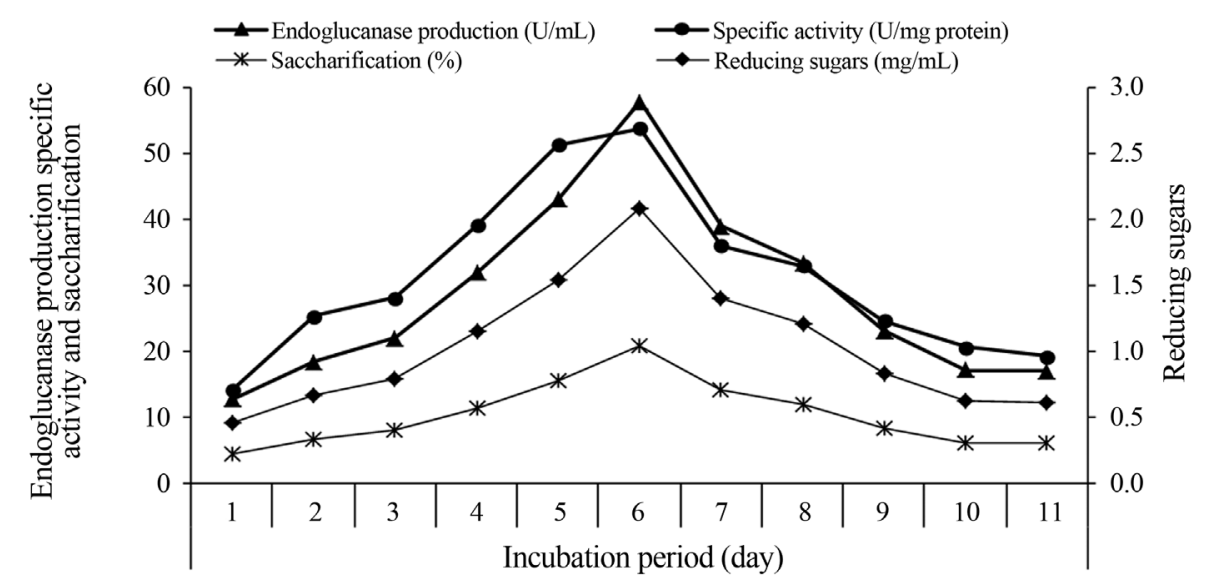

Figure 6 - Effect of incubation periods on endoglucanase production, reducing sugars level and saccharification of sugarcane bagasse by S. albogriseolus subsp. cellulolyticus. 


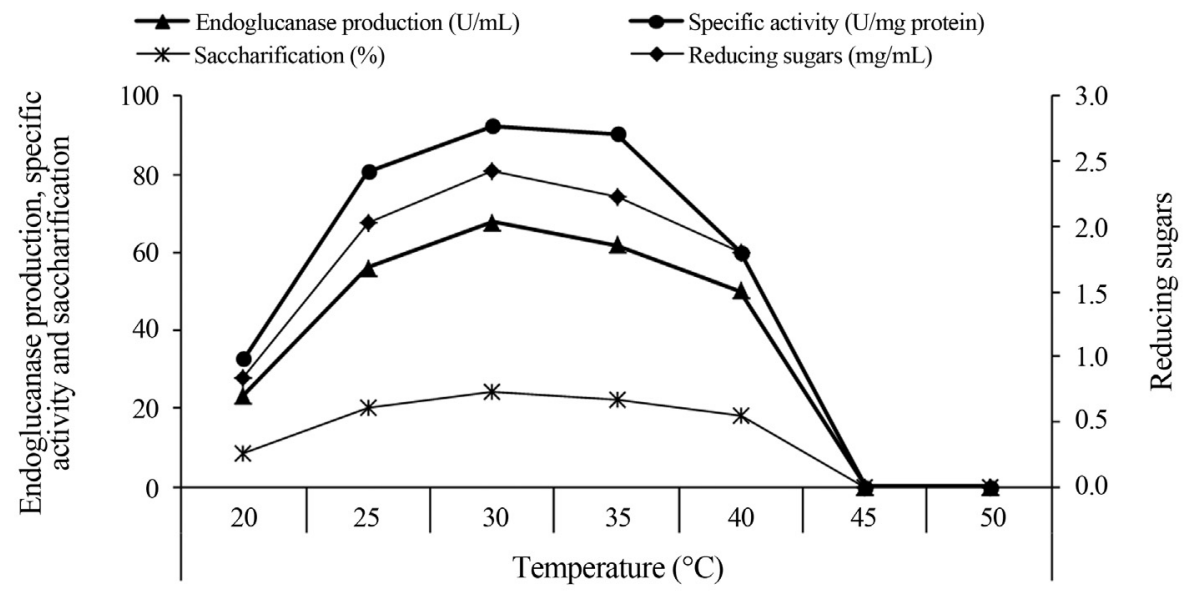

Figure 7 - Effect of temperature on endoglucanase production, reducing sugars level and saccharification of sugarcane bagasse by S. albogriseolus subsp. cellulolyticus.

showed that the optimum temperature for endoglucanase from a strain of Streptomyces sp. strain NEAE-D was $35^{\circ} \mathrm{C}$.

\section{Effect of $\mathrm{pH}$ on endoglucanase production}

The effect of cultural $\mathrm{pH}$ on endoglucanase production by S. albogriseolus subsp. cellulolyticus was examined at various values ranging from 4.0 to 9.0 as shown in Figure 8 . The enzyme shows high activity $(78.26 \mathrm{U} / \mathrm{mL})$, reducing sugars $(2.82 \mathrm{mg} / \mathrm{mL})$ and saccharification $(28.16 \mathrm{mg} / \mathrm{mL})$ at $\mathrm{pH} 6.5$. The enzyme production reduced by $49.91 \%$ at $\mathrm{pH}$ 8. Similarly, Streptomyces omiyaensis (Alam et al., 2004) and S. viridochromogenes (El-Naggar et al., 2011) recorded high cellulase activity at $\mathrm{pH} 6.5$. Streptomyces sp. F2621 (Tuncer et al., 2004) and $S$. albogriseous (Van Zyl, 1985) also exhibited maximum endoglucanase activity at initial $\mathrm{pH}$ of 6.5-7.0. On the other hand, the results appeared to contradict with these reported by Theberge et al. (1992) in which, the optimum $\mathrm{pH}$ for endoglucanase from a strain of Streptomyces lividans was 5.5. Sherief et al. (2010) showed that the optimum $\mathrm{pH}$ for maximum production of CMCase from a strain of Aspergillus fumigatus was 5.5.

\section{Influence of different nitrogen sources on endoglucanase production}

In an attempt to maintain low fermentation costs during endoglucanase production, relatively inexpensive organic nitrogen sources (yeast extract, peptone and casein) and inorganic nitrogen sources (ammonium chloride, ammonium phosphate, potassium nitrate, sodium nitrate and urea) were used (Table 4). Among the nitrogen sources tested, peptone proved to be the best nitrogen source for enzyme production $(107.71 \mathrm{U} / \mathrm{mL})$ followed by yeast extract $(94.82 \mathrm{U} / \mathrm{mL})$. Peptone moreover, recorded the highest values of both reducing sugars and saccharification, confirm-



Figure 8 - Effect of $\mathrm{pH}$ on endoglucanase production, reducing sugars level and saccharification of sugarcane bagasse by S. albogriseolus subsp. cellulolyticus. 
Table 4 - Effect of different nitrogen sources on endoglucanase production, reducing sugars level and saccharification of sugarcane bagasse by $S$. albogriseolus subsp. cellulolyticus.

\begin{tabular}{lcccc}
\hline Nitrogen Source & $\begin{array}{c}\text { Endoglucanase activity } \\
(\mathrm{U} / \mathrm{mL})\end{array}$ & $\begin{array}{c}\text { Specific activity } \\
(\mathrm{U} / \mathrm{mg} \text { protein })\end{array}$ & $\begin{array}{c}\text { Reducing sugars } \\
(\mathrm{mg} / \mathrm{mL})\end{array}$ & $\begin{array}{c}\text { Saccharification } \\
(\%)\end{array}$ \\
\hline Control & 37.02 & 141.28 & 1.33 & 13.32 \\
$\mathrm{NaNO}_{3}+$ Yeast extract & 84.98 & 75.54 & 3.06 & 30.58 \\
$\mathrm{NaNO}_{3}$ & 66.39 & 66.86 & 2.39 & 23.89 \\
$\mathrm{KNO}_{3}$ & 79.34 & 84.22 & 2.85 & 28.55 \\
Urea & 77.41 & 160.63 & 2.79 & 27.85 \\
Peptone & 107.71 & 98.26 & 3.88 & 38.76 \\
Casein & 65.46 & 54.83 & 2.36 & 23.56 \\
$\mathrm{NH}_{4} \mathrm{Cl}$ & 70.17 & 125.62 & 2.52 & 3.41 \\
Yeast extract & 94.82 & 96.94 & 2.15 & 25.25 \\
$\mathrm{NH}_{4} \mathrm{H}_{2} \mathrm{PO}_{4}$ & 59.65 & 98.19 & & 34.12 \\
\hline
\end{tabular}

ing the good growth and biodegradation of sugarcane bagasse by S. albogriseolus subsp. cellulolyticus on peptone as the sole nitrogen source. With respect to specific activity of endoglucanase, no clear trend could be detected, this may be back to the variation among nitrogen sources in their composition, where the growth nature of $S$. albogriseolus subsp. Cellulolyticus varied, as a result, the secreted protein varied in quantity and quality, leading to various specific activity, so no much dependency could be relying on such parameter. Our results are in accordance with the work of Enari et al. (1977) who reported that good cellulase production could be obtained with the organic nitrogen sources such as yeast extract and peptone. Yeast extract suited for enhanced production of endoglucanase by Streptomyces sp. BRC2 (Chellapandi and Himanshu, 2008). Yeast extract for Streptomyces sp. F2621 (Tuncer et $a l ., 2004)$ is reported as potential nitrogen source for endoglucanase production. Peptone was found to be the best nitrogen source for exoglucanase production (Mukherjee et al., 2011).

\section{Conclusion}

Among different agro-industrial residues that used for endoglucanase production from Streptomyces albogriseolus subsp. cellulolyticus, the enzyme yield obtained from sugarcane bagasse is comparatively higher to that obtained from carboxymethyl cellulose. Therefore, it was thought that agro-industrial residues could be considered to be an alternative substrate for endoglucanase production by the novel subsp.; $S$. albogriseolus subsp. cellulolyticus. Besides that, it would be benefit for the economic endoglucanase production and alternative method to convert agricultural wastes into useful products.

\section{References}

Alam MZ, Manchur MA, Anwar MN (2004) Isolation, purification, characterization of cellulolytic enzymes produced by the isolate Streptomyces omiyaensis. Biol Sci 7:1647-1653.

Altschul SF, MaddenTL, Schaffer AA, Zhang J, Miller W, Lipman DJ (1997) Gapped BLAST and PSI-BLAST: A new generation of protein database search programs. Nucleic Acids Res 25:3389-3444.

Apun K, Jong BC, Salleh MA (2000) Screening and isolation of a cellulolytic and amylolytic Bacillus from sago pith waste. J Gen Appl Microbiol 46:263-267.

Ariffin H, Abdullah N, Umi Kalsom MS, Shirai Y, Hassan MA (2006) Production and characterization of cellulase by $B a-$ cillus pumilus EB3. Int J Eng Technol 3:47-53.

Azab EA, Ali MM, Fareed MF (2005) Studies on uricase induction in certain bacteria. Egyp J Biol 7:44-54.

Benedict R C, Shotwelt OL, Pridham T C, Lindenfelser L A, Haynes W C (1954) The production of the neomycin complex by Streptomyces albogriseolus, nov. sp. Antibiot Chemother 4:653-656.

Berdy J (1995) Are actinomycetes exhausted as a source of secondary metabolites? Biotechnologia 7-8:13-34.

Bhuyan BK, Dietz A, Smith CG (1962) Pactamycin, a new antitumor antibiotic. I. Discovery and biological properties. Antimicrob Agents Chemother 1961:184-190.

Chellapandi P, Himamhy M J (2008) Production of endoglucanse by the native strain of Streptomyces isolates in submerged fermentation. Braz J Microbiol 39:122-127.

Choi YJ, Kim EJ, Piao Z, Yun YC, Shin YC (2004) Purification and characterization of chitosanase from Bacillus sp. strain KCTC 0377BP and its application for the production of chitosan oligosaccharides. Appl Envir Microbiol 70:4522531.

Cowan ST, Steel KL (1974) Cowan and Steel's manual for the identification of medical bacteria. 2nd. Edition. Cambridge Univ. Press, Cambridge.

Dosoretz CG, Chen HC, Grethlein HE (1990) Effect of environmental conditions on extracellular protease activity in lignolytic cultures of Phanerochaete chrysosporium. Appl Environ Microbiol 56:395-400.

El-Naggar NE, Abdelwahed NAM (2012) Optimization of process parameters for the production of alkali-tolerant carbo- 
xymethyl cellulase by newly isolated Streptomyces sp. strain NEAE-D. Afric J Biotechnol 11(5):1185-1196.

El-Naggar NE, Sherief AA, Hamza SS (2011) Bioconversion process of rice straw by thermotolerant cellulolytic Streptomyces viridiochromogenes for production of bioethanol under SSF conditions. Afric J Biotechnol 10(56):11998-12011.

El-Naggar NE, Deraz S, Khalil A (2014) Bioethanol production from lignocellulosic feedstocks based on enzymatic hydrolysis: Current status and recent developments. Biotechnol 13: 1-21.

Enari TM, Markenan P (1977) Production of cellulolytic enzymes by fungi. Adv Biochem Eng 5:1-23.

Galante YM, De Conti A, Monteverdi R (1998) Application of Trichoderma enzymes in food and feed industries. In: Harman, G.F. and Kubicek, C.P. (eds) Trichoderma and Gliocladium: Enzymes, Biological Control and Commercial Applications. Vol. 2. Taylor and Francis, London, pp. 327-42.

Gill PK, Sharma AD, Harchand RK, Singh P (2003) Effect of media supplements and culture conditions on inulinase production by an actinomycete strain. Biores Technol 87:359-62.

Gordon RE, Barnett DA, Handerhan JE, Pang CHN (1974) Nocardia coeliaca, Nocardia autotrophica, and the nocardin strain. Int J Syst Bacteriol 24:54-63.

Gulati R, Saxena RK, Gupta R (1997) A rapid plate assay for screening L-asparaginase producing micro-organisms. Lett. Appl. Microbiol. 124: 23-26.

Harchand RK, Singh S (1997) Characterization of cellulase complex of Streptomyces albaduncus. J Basic Microbiol 37(2):93-103.

Hopkins DW, Bibb MJ, Chater KF, Kieser C, Bruton CJ, Kiezer HM, et al. (1985) Genetic Manipulation of Streptomyces. A Laboratory Manual. The John Innes Institute, Norwich.

Howard RL, Abotsi E, Jansen REL, Howard S (2003) Lignocellulose biotechnology: Issue of bioconversion and enzyme production. Afr J Biotechnol 2:602-619.

Hsu CL, Chang KS, Lai MZ, Chang TC, Chang YH , Jang HD (2011) Pretreatment and hydrolysis of cellulosic agricultural wastes with a cellulase-producing Streptomyces for bioethanol production. Biomass Bioen 35:1878-1884.

Kluepfel D, Shareck F, Mondou F, Morosoli R (1986) Characterization of cellulase and xylanase activities of Streptomyces lividans. Appl Microbiol Biotechnol 24:230-234.

Kotchoni OS, Shonukan OO, Gachomo WE (2003) Bacillus pumillus, BPCR16, a promising candidate for cellulase production under conditions of catabolic repression. Afr J Biotechnol 2:140-146.

Lechevalier MP , Lechevalier HA (1970) Chemical composition as a criterion in the classification of aerobic actinomycetes. Int J Syst. Bacteriol 20:435-443.

Lowry OH, Rosebrough NJ, Farr AL, Randall RJ (1951) Protein measurement with the Folin Phenol reagent. Bio Chem 193:265-75.

Miller GL (1959) Use of dinitrosalicylic acid reagent for determination of reducing sugar. Anal Chem 31:426-428.

Mishra S, Behera N (2008) Amylase activity of a starch degrading bacteria isolated from soil receiving kitchen wastes. Afric J Biotechnol 7(18):3326-3331.

Modi HA, Patel KC, Ray RM (1994) Solid state fermentation for cellulase production by Streptomyces sp HM-29. In: Pandey
A, ed. Solid State Fermentation. Wiley Eastern Publishers, New Delhi, p. 137-141.

Montenecourt BS, Eveleigh DE (1977) Semiquantitative plate assay for determination of cellulase production by Trichoderma viride. Appl. Environ Microbiol 33(1):178-183.

Mukherjee S, Karmakar M, Ray RR (2011) Production of extra cellular exoglucanase by Rhizopus oryzae from submerged fermentation of agrowastes. Rec Res Sci Tech 3:69-75.

Nitsch B, Kutzner HJ (1969) Egg-yolk as a diagnostic medium for streptomycetes. Experientia 25:113-116.

Ogel ZB, Yarangumeli K, Dundar H, Ifrij I (2001) Submerged cultivation of Scytalidium thermophilum on complex lignocellulosic biomass for endoglucanase production. Enz Microb Technol 28:689-695.

Ojumu TV, Solomon BO, Betiku E, Layokun S K, Amigun B (2003) Cellulase production by Aspergillus flavus Linn isolate NSPR 101 fermented in sawdust, bagasse and corncorb. Afric J Biotechnol 2:150-152.

Oliveira LA, Porto ALF, Tambourgi EB (2006) Production of xylanase and protease by Penicillium janthinellum CRC $87 \mathrm{M}-115$ from different agricultural wastes. Bioresour Technol 97:862-867.

Pandey A, Soccol CR, Nigam P, Soccol VT (2000) Biotechnological potential of agro-industrial residues I, sugar cane bagasse. Biores Technol 74:69-80.

Pragya R, Yasmin A, Anshula J (2012) An insight into agricultural properties of actinomycetes. Int J Res BioSci 1:7-12.

Pridham TG, Hesseltine CW, Benedict RG (1958) A guide for the classification of streptomycetes according to selected groups. Appl Microbiol 6:52-79.

Saitou N, Nei M (1987) The neighbor-joining method: a new method for reconstructing phylogenetic trees. Mol Biol Evol 4:406-425.

Sambrook J, Fritsch EF, Maniaties T (1989) Molecular Cloning: A Laboratory Manual $2^{\text {nd }}$ Cold. Spring, Harbor Laboratory press, Cold Spring Harbor, New York, USA.

Schrempf H, Walter S (1995) The cellulolytic system of Streptomyces retyiculi. Int J Macromolecules 15:353-355.

Sherief AA, El-Naggar NE, Hamza SS (2010) Bioprocessing of lignocellulosic biomass for production of renewable bioethanol using thermotolerant Aspergillus fumigates under solid state fermentation conditions. Biotechnol 9:513-522.

Shirling EB, Gottlieb D (1966) Methods for characterization of Streptomyces species. Int. J Syst Bacteriol 16:313-340.

Staneck JL, Roberts GD (1974) Simplified approach to identification of aerobic actinomycetes by thin layer chromatography. Appl Microbiol 28:226-231.

Tamura K, Dudley J, Nei M, Kumar S (2007). MEGA4: Molecular Evolutionary Genetics Analysis (MEGA) software version 4.0. Mol Biol Evol 24:1596-1599.

Theberge M, Lacaze P, Shareck F, Morosoli R, Kluepfel D (1992) Purification and characterization of an endoglucanase from Streptomyces lividans 66 and DNA sequence of the gene. Appl Microbiol 58:815-820.

Tresner HD, Hayes JA, Backus EJ (1968) Differential tolerance of streptomycetes to sodium chloride as a taxonomic aid. Appl Microbiol 16:1134-1136.

Tuncer M, Kuru A, Isikli M, Sahin N, Celenk FG (2004) Optimization of extra-cellular endoxylanase, endoglucanase and 
peroxidase production by Streptomyctes sp. F2621 isolated in Turkey. J Appl Microbiol 97(4):783-791.

Van Zyl WH (1985) A study of the cellulases produced by three mesophilic actinomycetes grown on bagasse as substrate. Biotechnol Bioengi 27(9):1367-1373.

Waksman SA, Lechevalier HA (1953) Guide to the classification and identification of the actinomycetes and their antibiotics. The Williams \& Wilkins Co., Baltimore.

Waksman SA (1959) Strain specificity and production of antibiotic substances. Characterization and classification of species within the Streptomyces griseus group. Proc Natl Acad Sci USA 45:1043-1047.

Waksman SA (1961) The actinomycetes, classification, identification and descriptions of genera and species. Vo. 2. The Williams and Wilkins Company, Baltimore, pp 61-292.
Williams ST (1985) Actinomycete ecology: a critical evaluation. In: Szabo, G., Biro,S. and Goodfellow, M. (eds) Sixth International Symposium on Actinomycete Biology. Elsevier, New York, pp 693-700.

Williams ST, Goodfellow M, Alderson G, Wellington EMH, Sneath PHA, Sackin MJ (1983) Numerical classification of Streptomyces and related genera. J Gen Microbiol 129:1743-813.

Williams ST, Goodfellow M, Alderson G (1989) Genus Streptomyces Waksman and Henrici 1943, 339AL. In: Williams ST, Sharpe ME, Holt JG (eds) Bergey's Manual of Systematic Bacteriology. vol 4. Williams and Wilkins, Baltimore, pp 2452-2492.

All the content of the journal, except where otherwise noted, is licensed under a Creative Commons License CC BY-NC. 